ISSN 0103-5150

Fisioter. Mov., Curitiba, v. 28, n. 4, p. 751-758, Oct./Dec. 2015

Licenciado sob uma Licença Creative Commons DOI: http://dx.doi.org.10.1590/0103-5150.028.004.A012

\title{
Continuous therapeutic ultrasound in the healing process in rat skin
}

\author{
Ultrassom terapêutico contínuo no processo \\ de cicatrização em pele de ratos
}

\section{Viviani de Marque Carrer ${ }^{[a]}$, João Antonio Palma Setti ${ }^{[b]}$, Djanira da Luz Veronez ${ }^{[c]}$, Auristela Duarte Moser ${ }^{[\mathrm{a}] *}$}

[a] Pontifícia Universidade Católica do Paraná (PUCPR), Curitiba, PR, Brazil

[b] Universidade Tecnológica Federal do Paraná (UTFPR), Curitiba, PR, Brazil

[c] Universidade Federal do Paraná (UFPR), Curitiba, PR, Brazil

\begin{abstract}
Introduction: The therapeutic ultrasound is one of the main resources utilized on physical therapy to stimulate the healing due its thermal and mechanic effects. However, your application still not properly standardized. Objective:To analyze the presence of the collagens types I and III stimulated by the ultrasonic wave in continuous mode at the cutaneous injury local for first intention. Material and methods: It was utilized 90 Wistar rats, young adults, with average weight of $230 \mathrm{~g}$, divided in 3 groups of 30 animals: control group, treated with ultrasound off; group 1, treated with ultrasound $0.5 \mathrm{~W} / \mathrm{cm}^{2}$ and group 2 , treated with ultrasound $2.0 \mathrm{~W} / \mathrm{cm}^{2}$. Each group was subdivided in 3 subgroups according with the healing phases, 3, 7
\end{abstract}

\footnotetext{
* VMC: MSc, e-mail: vivicarrer@gmail.com JAPS: PhD, e-mail: setti@utfpr.edu.br DLV: PhD, e-mail: djaniraveronez@gmail.com ADM: PhD, e-mail: auristela.lima@gmail.com
} 
and 21 days of consecutive therapeutic sessions. The ultrasound therapy began 24 hours after the termination of the surgical act, at the dorsal region, applying frequency of $3 \mathrm{MHz}$ and intensities $0.5 \mathrm{~W} / \mathrm{cm}^{2}$ and $2.0 \mathrm{~W} / \mathrm{cm}^{2}$ during 5 minutes under sliding technique. Later, the animals were sacrificed according to the healing phases for removal of incisional area and histological analyses. Conclusions: The results allowed conclude that the continuous mode of therapeutic ultrasound in the intensities $0.5 \mathrm{~W} / \mathrm{cm}^{2}$ and $2.0 \mathrm{~W} / \mathrm{cm}^{2}$ promoted stimulus to formation of collagens types I and III in the lesion area for first intention.

Keywords: Continuous ultrasound. Healing. Skin.

\section{Resumo}

Introdução: $O$ ultrassom terapêutico é um dos principais recursos utilizados na fisioterapia para estimular a cicatrização devido aos seus efeitos térmicos e mecânicos. No entanto, sua aplicação ainda não está devidamente padronizada. Objetivo: Analisar a presença dos colágenos tipos I e III estimulados pela onda ultrassônica no modo contínuo no local da lesão cutânea por primeira intenção. Materiais e métodos: Foram utilizados 90 ratos Wistar, adulto-jovens, com peso médio de $230 \mathrm{~g}$, divididos em 3 grupos de 30 animais: grupo controle, tratado com ultrassom desligado; grupo 1, tratado com ultrassom 0,5 W/cm e grupo 2, tratado com ultrassom 2,0 W/cm . Cada grupo foi subdividido em 3 subgrupos de acordo com as fases de cicatrização 3, 7 e 21 dias de sessões terapêuticas consecutivas. A terapia ultrassônica teve início 24 horas após o término do ato cirúrgico, na região dorsal, aplicando frequência de $3 \mathrm{MHz}$ e as intensidades 0,5 W/cm e 2,0 W/cm no tempo de 5 minutos sob a técnica de deslizamento. Posteriormente, os animais foram sacrificados de acordo com as fases de cicatrização para remoção da área incisional e análise histológica. Conclusão: Os resultados possibilitaram concluir que o modo contínuo do ultrassom terapêutico nas intensidades $0 \mathrm{~W} / \mathrm{cm}^{2}$ e 2,0 W/cm promoveu estímulo para formação dos colágenos tipos I e III na área da lesão por primeira intenção.

Palavras-chave: Ultrassom contínuo. Cicatrização. Pele.

\section{Introduction}

After a surgical act, usually, it is done the application of anti-inflammatory and anti-infective resources as preventive and therapeutic forms. It is expected in the sequence a normal range in the repair process at the local surgical incision.

Healing it's a complex process that involves different steps that any change in one of them interferes in the normal repair process, causing functional, morphological and aesthetic problems at the scar local.

The deficient formation of a scar absent from infection occurs due an improperly deposit of the granulation tissue and excessive accumulation of collagen, taking to dehiscence, ulceration wound and formation of keloid (1).

The high incidence at the pursuit of treatments that prevent undesirable scars formation as hypertrophic and keloid, stimulates the development of researches with resources that may prevent or help in the scar quality. In this sense, the physical therapy uses the therapeutic ultrasound to promote the healing.

Fyfe and Chahl (2) demonstratedin vivo experiment that the ultrasound stimulates the liberation of granules by mast cells. These granules release chemotactic agents that attract leukocytes to the injury.

Low and Reed (3) using therapeutic ultrasound report improvement in the scar quality and decrease of the fibrous tissue. At the same way, they note that the speed of closure of the wound healing and their contractions rates also were modified significantly with the use of therapeutic ultrasound.

According to Starkey (4), ultrasound quickens the inflammatory phase in the process of tissue healing, influencing positively the macrophages activity by application of continuous mode.

The ultrasonic vibration promotes a tissue heating, influences the cell metabolism, blood circulation and the increase of extensibility of collagen structures; raising the local temperature up to $113^{\circ} \mathrm{F}$, without injures. According to Dyson (5) the prevalence of 
thermal effect over the mechanic effect occurs in the intensities superior than $1 \mathrm{~W} / \mathrm{cm}^{2}$, continuous mode on frequencies $1 \mathrm{MHz}$ or $3 \mathrm{MHz}$.

According to DeDeyne and Kirsch-Volders (6) the ultrasound therapy stimulates the activity of inflammatory cells, resulting in the production of chemical mediators, responsible for the activation of fibroblasts and consequently the collagen synthesis.

The goal of this research was evaluate the ultrasonic therapy efficacy on the intensities of $0.5 \mathrm{~W} / \mathrm{cm}^{2}$ and $2.0 \mathrm{~W} / \mathrm{cm}^{2}$, usually utilized, in continuous mode with application time of 5 minutes for posterior analyses of the collagens types I and III, components responsible in the repair and healing process in skins of rats submitted to wounds by first intention.

\section{Material and methods}

On this experimental study were utilized 90 albinos rats of the lineage Wistar (Rattusnovergicusalbinus) male, average age of 100 days old and average weight of $230 \mathrm{~g}$. These animals were maintained in cages with the same room conditions, cycle light/dark of 12 hours receiving water and food ad libidum, during the 22 days of experiment. The Wistar rat was chosen because it's an animal of ease obtaining and handling in the vivarium. The dorsal region was selected for the surgical procedure because is relatively less exposed to contaminations, by minor contact of urine of the animal, decreasing the infection risks. Regarding the regeneration process, the Wistar rat presents both skin composition as capacity of tissue regeneration similar to humans.

The research was approved under number 403, issued by Animal Experimentation Ethics Committee PUCPR, by the Law 6638 and recommendations of the Brazilian School of Animal Experimentation.

The animals were anesthetized with the association of drugs Ketamine $(60 \mathrm{mg} / \mathrm{mg}$ ) and Xylazine $(10 \mathrm{mg} / \mathrm{kg}$ ) managing $0.2 \mathrm{ml}$ for each $100 \mathrm{~g}$ of animal weight, intramuscular, in the semitendinosus muscle, in the posterior thigh region. Then, the animals were positioned in ventral decubitus, fixing their inferior and superior members in wood supports for dorsal trichotomy performance. Later, were done surgical incision of $4 \mathrm{~cm}$ of length, standardized, with help of a manual caliper. Then, the exposure of skin and subcutaneous tissue was done, which were sutured with nylon wire 2.0 , simple.
After the end of the surgical act, the animals received Cephalexin in concentration of $15 \mathrm{mg} / \mathrm{kg}$, single application by subcutaneous way, during 5 days.

The experimental animals were divided in three groups, each one of them with 30 samples, organized in control group, group 1 and group 2, for application of ultrasonic therapy on intensities $0.5 \mathrm{~W} / \mathrm{cm}^{2}$ and $20 \mathrm{~W} / \mathrm{cm}^{2}$, respectively.

In sequence, the animals were redistributed in three subgroups, with 10 samples. The same were exposed to ultrasonic therapy with frequency of 3 $\mathrm{MHz}$, in continuous mode, in the period of 3, 7 and 21 consecutive days.

After the ultrasonic therapy, the animals were anesthetized according to protocol above, keeping the treatment time under anesthetic effect. The application time of ultrasonic therapy was standardized for 5 minutes, once a day, under sliding technique on the wound. For skin-head coupling were utilized gel based on water and carbopol.

The conventional equipment of ultrasound utilized (KLD Avatar V-US9705 model) had your average potency measured before the beginning of the experiment by means of a dosimeter of accuracy (Ultra Sonic Power Meter ${ }^{\circledR}$ model UPM-DT-1) on UTFPR (Federal Technological University of Paraná).

In each predetermined period, after the end of application of ultrasonic therapy, all the experimental animals of the different groups were submitted to euthanasia by lethal dose of intraperitoneal sodium thiopental $(120 \mathrm{mg} / \mathrm{kg})$.

After euthanasia, it was done the removal of a segment of the back where were the scar. The segments intended to histology were fixed in solution of formaldehyde at 10\% during 72 hours and alcohol $70 \%$ until the beginning of dehydration. Four cuts of each sample from ends and center of the scar were selected. After inclusion in paraffin blocks, they were submitted to cuts of four micrometers, preparing the blades with 4 cuts in each blade.

The blades were stained by the method Masson's PricosiriusHematoxilina. This histochemical technique consists basically on the staining of the collagen protein in the epithelium of regeneration.

For the histomorphological and histomorphometric analyses were utilized a microscope (Olympus BX50) with cameras of capture 3CCD post-series and the program of pictures capture ImageProPlus version 4.5 from Cybernetics ${ }^{\circledR}$. 
The pictures were captured by a camera Olympus ${ }^{\circledR}$ DP71, 12 megapixels, sent to a monitor Sony Trinitron ${ }^{\circledR}$ colorful with native resolution of $1.280 \times$ 1.024 pixels pitch $0.264 \mathrm{~mm}$, frost and digitalized by a digitizer board Oculus TCX ${ }^{\circledR}$ (coreco). Then, they were analyzed by the app ImageProPlus 4.5 for Windows ${ }^{\circledR}$ in a computer Pentium $\mathrm{III}^{\circledR}$.

For each blade was performed reading in three fields following the scar track, with enlargement of $40 x$, for the quantification of collagens types I and III stained in Picrosirius with polarized light. Initially, it had calibration between the captured pictures and the programs ImageProPlus version 4.5, when manually were selected the colors yellow-orange, green and black for distinction between the types of collagens I and III and background.Then, the program automatically quantified the selected area, and data obtained were archived in an Excel spreadsheet.

The statistic analyses, from the results obtained by the reading of the collagens types I and III were expressed by averages, medians, minima, maxima in graphics and charts.

For the comparison of the groups were utilized the statistic model of variance analyses and the test LSD for multiple comparisons. The values of $\mathrm{p}<005$ indicates significant statistic for the variable collagen type III.

\section{Results}

The group 1 presente total regeneration of the epidermis and dermis with preservation of the muscular layer. It is identified the presence of dermis attachments of the scar region in addition to your preservation in this tissue in the groups control and group 1. Presentation of the collagen type I and collagen type III in the incisional area indicating the repair.

Analyzing qualitatively the healing of the group treated with ultrasound $3 \mathrm{MHz}$ continuous mode, intensity $2.0 \mathrm{~W} / \mathrm{cm}^{2}$ (group 2), we could see in all studied animals the formation of surface with a neoformed tissue, regenerated irregularly, compound by collagen type III, in the green coloration. In this group we noticed necrosis, with lost of the tissues in the incision local, supposedly promoted by the treatment, disabling local analyses. The data of this group were obtained from the documentation and quantification only of the picture of the incision edges.
Initially, both for collagen I as collagen III, it was tested the null hypothesis of interaction nonexistence between group (control: group 1 treated with ultrasound of $3 \mathrm{MHz}$, continuous, $0 \mathrm{~W} / \mathrm{cm}^{2}$ of intensity and group 2. Treated with ultrasound of $3 \mathrm{MHz}$, continuous mode, $20 \mathrm{~W} / \mathrm{cm}^{2}$ of intensity) and sacrifice moment $(3,7$ and 21 days) versus the alternative hypothesis of interaction existence. The test result indicated the rejection of the null hypothesis $(\mathrm{p}<$ 0.001 ). This way, wasn't possible evaluate simultaneously both factors (group and moment) and the analysis continued comparing the groups in each sacrifice moment and comparing each sacrifice moment inside each group.

\section{Variable: Collagen type I}

Considering each moment of sacrifice, it was tested the null hypothesis that the collagen I average is equal for the three groups of study, versus the alternative hypothesis that at least one group have an average different from the others. For the comparison that had significant difference between the groups $(\mathrm{P}<0.05)$, it was done the comparisons of the groups two by two.

In 21 days of therapy, it was observed the difference of the quantified average of the collagen type I areas between the intensities, presenting significant responses with $\mathrm{p}<0.001$.

Its valid to highlight that the measured data of collagen type I in the group treated with intensity $2.0 \mathrm{~W} / \mathrm{cm}^{2}$ were quantified at the incisional line edges, because in the central line was zero.

\section{Variable: Collagen type III}

Considering each sacrifice moment, it was tested the null hypothesis that collagen III average is equal for the three groups of study, versus the alternative hypothesis that at least one group have a different average from the others.

The collagen type III variable in your times and intensities. It's notorious the bad performance of the ultrasonic therapy in the intensity $2.0 \mathrm{~W} / \mathrm{cm}^{2}$, which, in all moments demonstrated low effectiveness when compared to the control group and of higher intensity. The increase not significant of the collagen type III 
variable, in 21 days, of the groups 1 and 2 indicated the delay in the healing process.

\section{Discussion}

The protocol of this research was based on the one described by Harvey et al. (7), which was applied the continuous ultrasound $3 \mathrm{MHz}$, on the intensities $0.5 \mathrm{~W} / \mathrm{cm}^{2}$ and $2,0 \mathrm{~W} / \mathrm{cm}^{2}$ during 4 days. In this work, the authors observed increased synthesis of collagen in the results presented. This fact influenced the elaboration of this research protocol based on the application of the ultrasound in continuous mode on frequency $3 \mathrm{MHz}$, on the intensities $0.5 \mathrm{~W} / \mathrm{cm}^{2}$ and $2.0 \mathrm{~W} / \mathrm{cm}^{2}$, however, the time scale was inspired on the different phases of the repair process.

The works that validates the continuous mode of wave emission when applied under skin injury are few. By the findings, notably, the ultrasound effectiveness in continuous mode was proved in several protocols of repairs of different tissues that compose bones, tendons, muscles $(8,9,10)$. In skin repair, today, the pulsed ultrasound is most frequently used than the continuous ultrasound on the repair phases of the skin, due the not thermal or micro-thermal effects according to Watson (11) report.

Under this perspective, Byl et al. (12) compared the continuous mode with the pulsed mode, concluding that it have more deposition of collagen in injuries of pork skin on the intensity $0.5 \mathrm{~W} / \mathrm{cm}^{2}$ during 5 minutes of wave exposure.On the other hand,Cambier and Vandestraeten (13) don't observed significant difference between the modes on the healing of burns in rats.

According to Boucaud et al. (14) from exposure of human and rats skin segments, in vivo and in vitro, at therapeutic ultrasound of frequency $20 \mathrm{kHz}$ and intensity of $0.25 \mathrm{~W} / \mathrm{cm}^{2}$ to $7.0 \mathrm{~W} / \mathrm{cm}^{2}$ borderline, in continuous and pulsed modes, they observed erythema after exposure from the intensity $2.5 \mathrm{~W} / \mathrm{cm}^{2}$, dermal injury and muscle necrosis after 24 hours.

In this same context, TerHaar (15) reports that most of the researches developed with the pulsed mode indicates that it have more benefits in the repair of soft tissues than the continuous mode, in intensities not exceeding $0.5 \mathrm{~W} / \mathrm{cm}^{2}$. On the same way, there is evidences that the ultrasound on modes continuous and pulsed, with frequency $1.5 \mathrm{~W} / \mathrm{cm}^{2}$ it's more effective than the ultrasound on frequency $3 \mathrm{MHz}$.

Time, stimulation frequency, intensity and tissues standardization regenerated from ultrasonic therapy, in the continuous mode, present wide variation in the literature consulted (16).

It is necessary highlight that for precaution and prevention, the ultrasonic therapy was initiated 24 hours after the surgery. This fact is justified because isn't indicated the use of ultrasound during bleeding, because it increases blood flow in the continuous mode.

The ultrasonic therapy was applied during 5 minutes daily. The application sequence occurred during the 3 first days (inflammatory phase), 7 days (proliferative phase) and 21 days (remodeling phase).

It is notorious that in the inflammatory phase (3 days) the ultrasound haves stimulating effect on mast cells, platelets, leukocytes, macrophages (11). According to Leung et al. (17); Mortimer and Dyson (18); Nussbaum (19) the application of ultrasound induces to the degradation of mast cells. This result improves the quality and normality of inflammatory events. Despite not being the focus of this work to analyze the alterations of cell on inflammatory phase, it was identified, on this phase, epidermal thickening and beginning of granulation tissue formation on the incision local.

It is known that, also, on the proliferative phase (7 days), the stimulating effect occurs specially in fibroblasts, myoblasts and endothelial cells. On the analyses of the results in this phase it was identified intense presence of granulation tissue, better observed on group 1.

The results obtained in group 1 in the time of 21 days, when compared to the control group and analyzed by polarization, demonstrates increase on the quantity of collagen types I and III, suggesting successive steps of the repair process from the formation in layers of the neoformed tissue.

According to protocol established by Dyson (20) and adopted in this experiment, time application of 5 minutes was enough to generate thermal and nonthermal effects.

Harvey et al (7) verified the continuous ultrasound $3 \mathrm{MHz}$, on the intensities $0.5 \mathrm{~W} / \mathrm{cm}^{2}$ and $2.0 \mathrm{~W} / \mathrm{cm}^{2}$ during 4 days. They reported significant increase of protein synthesis and alteration of cell membrane, beyond the quantity of fibroblast, which resulted in increased synthesis of collagen. Corroborating with 
these results, comparing the collagen type III quantity of the control group with group 1 , there is a significant increase of this component.

The obtained results from the histomorphological analyses in all studied animals of group 1 presented higher capacity of regeneration and greater amount of granulation tissue typical of tissue repair, inside the time period of 7 days.

$\mathrm{Ng}$ and Fung (21), in experimental study with rats, analyzed the therapeutic ultrasound on continuous mode on the intensities $0.5 \mathrm{~W} / \mathrm{cm}^{2}, 1.2 \mathrm{~W} / \mathrm{cm}^{2}$ and control in 22 therapeutic sessions with application time of 1 minute. They observed that the three intensities were better when compared to control and didn't have significant difference between them on collagen fiber density of Achilles tendon. Justifying that the high intensity used in a short time period of application stimulates the regeneration of the collagen independent of the dosage.

The therapeutic ultrasound, despite being utilized with frequency, stilldoesn't have your therapeutic protocols standardized and scientifically validated. In this analyses form, the frequency most utilized on the superficial tissues as the skin, according to Hoogland (22), its $3 \mathrm{MHz}$. In the same way, several authors reproduced the intensity $0.5 \mathrm{~W} / \mathrm{cm}^{2}$ in their experiments, in orderof repair $(23,24,25)$.

Although have reproducibility on the frequency and intensity in the applied methods on ultrasonic therapy, it seems that doesn't exist established parameters of dosimetry and presence of discrepancy on the analyses of penetration depth of ultrasonic emission and absorption degree by the tissues $(22,3$, $26,27)$.

The same way, Sá et al. (28) reported that have scant scientific evidences of the ultrasound effects on biological tissues, relating this fact to numerous methodological flaws, including relation of the area size of effective radiation with the injury extension and mostly information about calibration of apparatus.

In this work, the ultrasonic equipment was submitted to measurement with dosimeter precision, to certificate the intensity of transducer output with premise of prepare the appliance in a efficient way to generate the biophysical effects expected in the regeneration tissue.

According to the security rules of International Electrotechnical Commission about the therapeutic ultrasound equipment, commonly utilized on physical therapy, some limits for the patient protection are highlighted. One of these limits is the transducer temperature in the front face, not exceeding $106^{\circ} \mathrm{F}$ when operated underwater (29).

Allen (30) and TerHaar (26) relate that the continuous ultrasound heating increases the extensibility of the collagen, minimize adhesions, reduce the painful nociceptive threshold and promotes muscle relaxation.

On the analyses of the obtained results from the quantification of collagen type I in 3 days, it wasn't found significant data $(p=0089)$ between the intensity of the group treated and control group. Relevant benefits and harms that could suggest therapeutic indication or disability of the procedure in the protocols was not identified.

In this context, in the analyses of collagen presentation by the application of continuous mode wasn't possible to find the collagen extensibility due the adopted methodology. But, it was observed, from the quantitative analyses, an increase in the collagen type I in the surgical incision area, indicating the organization of neoformed tissue after 21 days of ultrasonic therapy on control group and group 1. In the same conditions, analyzing the therapy applied for 7 days, it was observed no significant difference $(p=1.75)$ in the collagen type I area quantification between control group and group 1. We found that the results average were similar between the low intensity of group 1 and control group.

In the analyses of collagen type III results, at the moment of 7 days of experiment, it was observed significant absence $(p>0.05)$ between the averages of the three studied groups. The best average presented was of the group treated with intensity $0.5 \mathrm{~W} / \mathrm{cm}^{2}$ indicating more concentration of collagen type III on the proliferative phase, confirming the ultrasonic stimulus.

It is important highlights that weren't found on literature similar results that could corroborate with the ones found in this research.

This method proved to be efficient for ultrasonic therapy applied in the treated group, of frequency $3 \mathrm{MHz}$, continuous mode, on intensity of $0.5 \mathrm{~W} / \mathrm{cm}^{2}$ and time periods of 7 days. Since was possible identify in all studied animals increased quantity of granulation tissue, better recovery and presentation of the skin attachments, satisfactory amount of collagens types I and III, demonstrating success on the repair. 
However, more studies are necessary to evaluate the ultrasonic therapy effects, in continuous mode regarding the dosage, frequency, time and number of applications.

\section{Final considerations}

The results obtained in this work allow to conclude that the ultrasonic therapy promotes the formation of collagens type I and III in the groups treated with intensities $0.5 \mathrm{~W} / \mathrm{cm}^{2}$ and $2.0 \mathrm{~W} / \mathrm{cm}^{2}$, in continuous mode for 5 minutes. There was greater amount of collagen type I at the end of the treatment with application on intensity $0.5 \mathrm{~W} / \mathrm{cm}^{2}$, proving the method effectiveness. However, there was increased formation of collagen type III in the same time period, suggesting the persistent stimulus and, consequently, persistence in the regeneration process in the groups stimulated by the ultrasonic wave.

The ultrasonic therapy $3 \mathrm{MHz}$, in continuous mode, with intensity $2.0 \mathrm{~W} / \mathrm{cm}^{2}$ presented unfavorable and incompatible results for the clinical application.

\section{References}

1. Abbas AK, Kumar V, Fausto N. Fundamentos de patologia. 7 ed. Rio de Janeiro: Elsevier; 2006.

2. Fyfe MC, Chahl LA. Mast cell degranulation: a possible mechanism of action of therapeutic ultrasound. Ultrasound in Medicine and Biology. 1982;8(1):62.

3. Low J, Reed A. Eletroterapia explicada. 3 ed. São Paulo: Manole; 2001.

4. Starkey C. Recursos terapêuticos em fisioterapia. 2 ed. São Paulo: Manole; 2001.

5. Dyson M. Mechanisms involved in therapeutic ultrasound. Physioterapy, London. 1987;73(3):116-20.

6. Dedeyene GP, Kirsch-Volders M. In vitro effects of therapeutic ultrasound on the nucleous of human fibroblasts. Physical Therapy. 1995;75:629-34.

7. Harvey W, Dyson M, Pond J. The Stimulation of protein synthesis in human fibroblast by therapeutic ultrasound. Rheumatology and Rehabilitatio. 1975;14:237.
8. Fernandes MAL, Alves GES, Souza JCA. Efeito do ultra-som terapêutico em tendinite experimental de equinos: estudo clínico, ultra-sonográfico e histopatológico de dois protocolos. Arquivo Brasileiro de Medicina Veterinária e Zootecnia. 2003;55(1):27-34.

9. Garavello I, Mazzer N, Barbieri CH, Andrade J. Efeitos térmicos do ultra-som terapêutico sobre os tecidos ósseo e muscular e sobre placa metálica implantada. Revista Brasileira de Ortopedia.1997;32(6).

10. Karnes JL, Burton HW. Continuous therapeutic ultrasound accelerate repair of contration-induced skeletal muscle damage in rats. Archives of Physical Medicine and Rehabilitation. 2002; 83:1-4.

11. Watson T. Ultrasound in contemporary physiotherapy practice. Ultrasonics. 2008;48:321-9.

12. Byl NN, Mckenzie A, Wong T, West J, Hunt TK. Incisional wound healing: a controled study of low and high dose ultrasound. Journal Orthopaedic Sports Physical Therapy. 1993;18(5): 619-28.

13. Cambier DC, Vanderstraeten GG. Failure of therapeutic ultrasound in healing burn injuries. Burns. 1997; 23(3):248-9.

14. Boucaud A, Machet L, Arbeille B, Machet MC, Montharu A, Patat F, Vaillant L. In vitro study of lowfrequency ultrasound-enhanced transdermal of fentanyl and caffeine across human and hairless rat skin. International Journal of Pharmaceutics. 2001;228: 69-77.

15. TerHaar G. Therapeutic applications of ultrasound. Progress in Biophysics and Molecular Biology. 2007; 93:111-29.

16. Polacow MLO, Dib-Giusti HK, Leonardi GR, Vieira CEC, Guirado GN, Zague V, Di Pierro R, Ribeiro MCA, Pires de Campos MSM. Efeito do ultra-som e do D-Pantenol na regeneração tegumentar. Revista Brasileira de Fisioterapia. 2005;9(3):365-71.

17. Leung MC, Ng G, Yip KK. Effect of ultrasound on acute inflammation of transected medial collateral ligaments. Archives of Physical of Medicine and Reabilitation, 2004;85:963-6. 
18. Mortimer AJ, Dyson M. The effect of therapeutic ultrasound on calcium uptake in fibroblasts. Ultrasound in Medicine and Biology. 1988;14(6).

19. Nussbaum EL. Ultrasound: to heat or not to heartthat is the question. The Physical Therapy Review. 1997;2:59-72.

20. Dyson M. Mechanisms involved in therapeutic ultrasound. Physioterapy, London. 1987;73(3):116-20.

21. Ng G, Fung DTC. The effect of therapeutic ultrasound intensity on the ultrastuctural morphology of tendon repair. Ultrasound in Medicine and Biology. 2007; 33(11):1750-4.

22. Hoogland R. Terapia ultrasonica. Espanha: EnrafNoniusDelft; 1986.

23. Alfredo PP, Anaruma CA, Pião AC, João SM, Casarotto RA. Effects of phonophoresis with arnica montana onto acute inflammatory process in rat skeletal muscles: na experimental study. Ultrasonics. 2009;49:466-71.

24. Dyson M, Pond JP, Joseph J, Warwick R. The stimulation of tissue regeneration by means of ultrasound. Clinical Science London. 1968;35(2):273-85.

25. Gonçalves AC, Barbieri CH, Mazzer N, Garcia C. Can therapeutic ultrasound influence the integration of skin grafts. Ultrasound in Medicine and Biology. 2007; 33(9):1406-12.
26. TerHaar G. Therapeutic ultrasound. European Journal Ultrasound. 1999;9:3-9.

27. Ward AR. Electricity, fields and waves in therapy. Marrickville, Australia: Science Press, 1980.

28. Sá JNB, Pereira WCA, Krüger MAV. Estudo do padrão de aquecimento por ultra-som fisioterapêutico em phantomultra-sônico com matriz de termopares. In: Anais do XXI Congresso Brasileiro de Engenharia Biomédica, São Pedro; 2008.

29. Duck FA. Medical and non-medical protection standards for ultrasound and infrasound. Review. Progress in Biophysics and Molecular Biology. 2007;93: 176-91.

30. Allen RJ. Physical agents used in the management of chronic pain by physical therapists. Physical Medicine and Reabilitation Clinics of North American. 2006;17:315-45.

Received: $12 / 15 / 2014$ Recebido: 15/12/2014

Approved: 05/26/2015 Aprovado: 26/05/2015 